\title{
Isolated Patent Ductus Arteriosus in an Elderly Female, Aged 65 Years-A Case Report
}

\author{
Ramachandran Muthiah \\ Zion Hospital, Azhagiamandapam, Kanyakumari District, India \\ Email: cardioramachandran@yahoo.co.uk
}

How to cite this paper: Muthiah, R. (2018) Isolated Patent Ductus Arteriosus in an Elderly Female, Aged 65 Years-A Case Report. Case Reports in Clinical Medicine, 7, 352-379.

https://doi.org/10.4236/crcm.2018.75033

Received: April 14, 2018

Accepted: May 25, 2018

Published: May 28, 2018

Copyright $\odot 2018$ by author and Scientific Research Publishing Inc. This work is licensed under the Creative Commons Attribution International License (CC BY 4.0).

http://creativecommons.org/licenses/by/4.0/

(c) (i) Open Access

\begin{abstract}
Aim: To report a case of longer-lived patent ductus arteriosus with features of pulmonary arterial hypertension up to the age of 65 years in an elderly woman. Introduction: The clinical recognition of patent ductus arteriosus with severe pulmonary hypertension is difficult. Only $60 \%$ of adults presented with a continuous murmur in a recent series. Asymptomatic patent ductus arteriosus tolerated for many years and may not require closure. Case Report: A 65 years old female presented with dyspnea had signs of pulmonary arterial hypertension with enlarged pulmonary artery and its branches, atrial fibrillation along with a continuous murmur in the left second intercostal space. Echocardiography revealed a $13 \mathrm{~mm}$ size patent ductus arteriosus and a bidirectional with predominant left-to-right shunt. Patient was managed conservatively and symptoms got improved with medical therapy. Conclusion: Treatment of patent ductus arteriosus in the setting of pulmonary hypertension is challenging. Early repair can mitigate the development of pulmonary hypertension and reverse vasculopathy in more advanced disease. Maternal aspirin ingestion should be avoided in pregnancy since it causes constriction of fetal ductus.
\end{abstract}

\section{Keywords}

Adult Ductus, Pulmonary Hypertension, Pulmonary Vasodilators, Transcatheter Closure, Wright Technique

\section{Introduction}

The Patent Ductus Arteriosus (PDA) is a vascular structure that connects the proximal descending aorta to the roof of the main pulmonary artery near the origin of its left main branch. It is defined as failure of the ductus arteriosus to close within 72 hours after birth [1] and some authors consider the patent duc- 
tus to be abnormal only after 3 months of age [2]. It is the third most common congenital cardiovascular anomaly, accounting for approximately 5\% to $10 \%$ of all congenital heart disease in children [3] and its incidence is approximately 1 in 2000 in full-term infants. It passes from the anterior aspect of the pulmonary artery to the posterior aspect of the aorta, approximately 5 to $10 \mathrm{~mm}$ distal to the origin of left subclavian artery and is twice as often in females than in males with a ratio of 2 or 3 to 1 [4] and the female prevalence is even greater in older patients [5]. The ductus may take many shapes and forms, from short and tubular to long and tortuous and typically has a conical shape with a large aortic end (ampulla) tapering with a small pulmonary connection, the narrowest segment. Thus, PDA morphology can vary and it is classified by the work of Krichenko and colleagues [6] as shown in Table 1 .

A ductus may have a tortuous morphology, usually observed in preterm and does not fit in this classification. It is larger, longer, tapers minimally from the aortic to pulmonary end, with a tortuous connection to the pulmonary artery, giving a "hockey-stick" appearance [7] and classified as type F or fetal type. Nearly $1 \%$ of children undergoing color Doppler studies were found to have PDA without auscultatory evidence of a murmur is termed as "silent ductus" [8].

Patent ductus arteriosus presenting in an elderly is unusual since majority are diagnosed early in life and treated. Patients can tolerate a very high pulmonary artery pressure for long periods without deterioration of their clinical status and those with minimal or reactive pulmonary hypertension and limited myocardial changes may have a normal life expectancy. A 20-year-old man with a patent ductus had been a cross-country runner [9] and a woman led an active life as a schoolmistress and died at the age of 85 years [10] because of gastrointestinal bleeding. There is an increasing awareness of patent ductus arteriosus in adulthood beyond 60 years [11] and the oldest documented patient lived to 90 years of age [12] and so this case had been reported.

\section{Case Report}

A 65-year-old acyanotic female was referred with a history of breathing difficulty for one month duration for cardiac evaluation. Her pulse rate was $100 \mathrm{bpm}$ and blood pressure 160/60 mmHg. Blood chemistry revealed normal. ECG revealed atrial fibrillation as in Figure 1. X-ray chest revealed enlargement of pulmonary

Table 1. Krichenko classification of patent ductus arteriosus morphology.

\footnotetext{
Type A (conical) Prominent aortic ampulla with narrowing at pulmonary artery end

Type B (window) Short and wide ductus with blending of pulmonary artery

Type C (tubular) Long tubular ductus with no constriction

Type D (complex) Multiple constrictions with complex ductus

Type E (elongated) Elongated ductus with remote constriction
} 


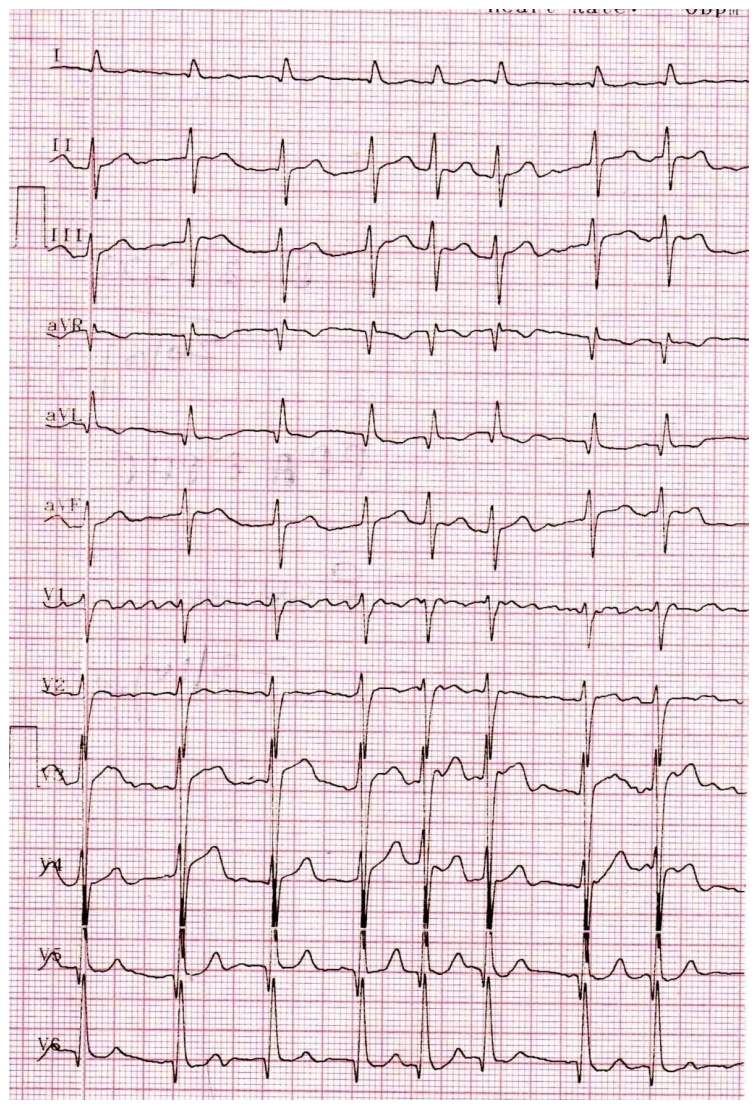

Figure 1. ECG showing atrial fibrillation in a 65 years old female.

arteries with ductal calcification as in Figure 2. Physical examination revealed bounding peripheral pulses due to wide pulse pressure, bilateral basal crackles and rhonchi in lung fields with continuous murmur at the left sternal border in the second and third intercostal spaces, which had uninterrupted progression through the second sound, punctuated by eddy sounds due to large flow and great turbulence in the later half of systole and first half of diastole [13] that vary from beat to beat, give the murmur a "machinery" quality with systolic accentuation (Gibson murmur) and it is not intermittent, which is a feature of acute angulation of elongated duct [14], [15], veil-like valve or structure within the ductal lumen at the pulmonary end [16] or a ductal membrane (sudden rupture) [17] and reappearance due to reopening of ductus after closure. Echocardiography revealed a $13 \mathrm{~mm}$ size ductus as in Figure 3, PDA (patent ductus arteriosus) jets as in Figures 4-8, features of pulmonary arterial hypertension as in Figures 9-14 with compensatory LVH (left ventricular hypertrophy) with intact atrial septum as in Figures 15-17.

The patient was treated conservatively with salbutamol nebulization, loop diuretics (furosemide $40 \mathrm{mg}$ once daily), antibiotics, calcium channel antagonists (amlodipine $2.5 \mathrm{mg}$ daily), warfarin $2.5 \mathrm{mg}$ on alternate days to prevent embolic episodes since the patient is in atrial fibrillation and oral sildenafil (40 mg once daily). The patient got better and advised periodic follow-up. 


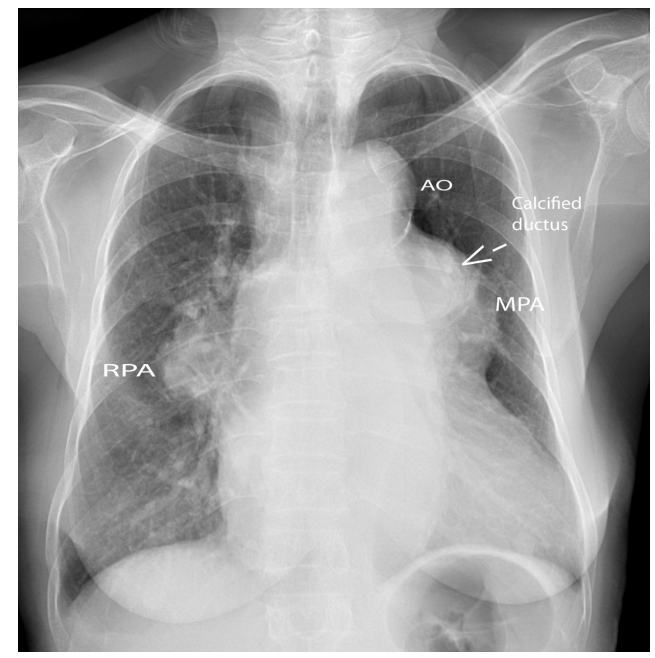

Figure 2. X-ray chest PA (postero-anterior) view showing calcified ductus (arrow), enlarged main pulmonary artery (MPA) and right pulmonary artery (RPA) suggesting pulmonary arterial hypertension (PHT) and mild cardiomegaly in a 65-year-old female. AO-aorta (aortic knuckle).

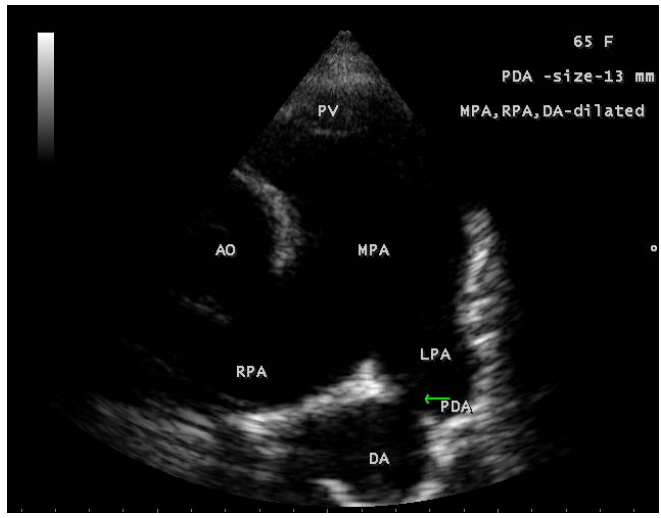

Figure 3. Short axis view showing the Patent Ductus Arteriosus (PDA) (arrow) in a 65-year-old female. PDA size is $13 \mathrm{~mm}$.

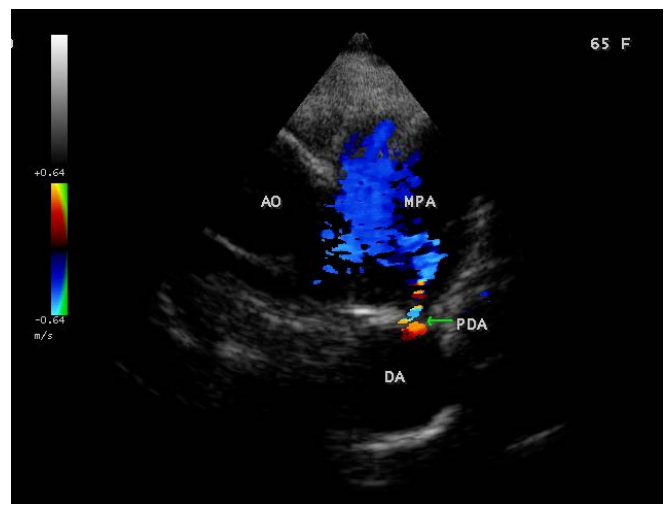

Figure 4. Short axis view showing the origin of ductal jet (arrow) in a 65-year-old female. 


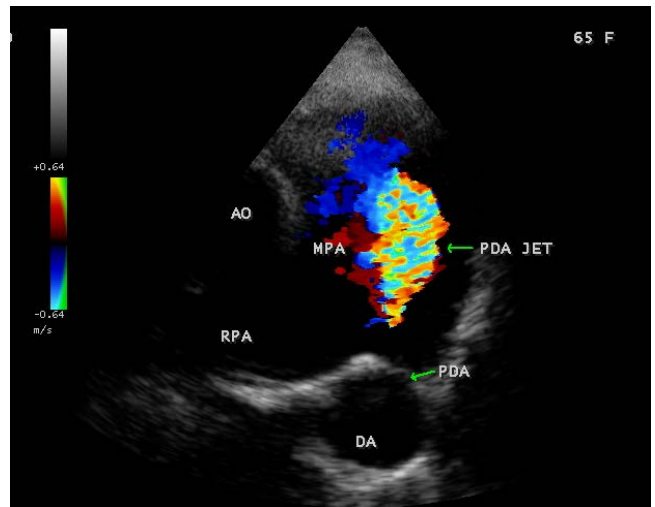

Figure 5. Short axis view showing the ductal (PDA-lower arrow) jet (upper arrow) in the main pulmonary artery in a 65-year-old female.

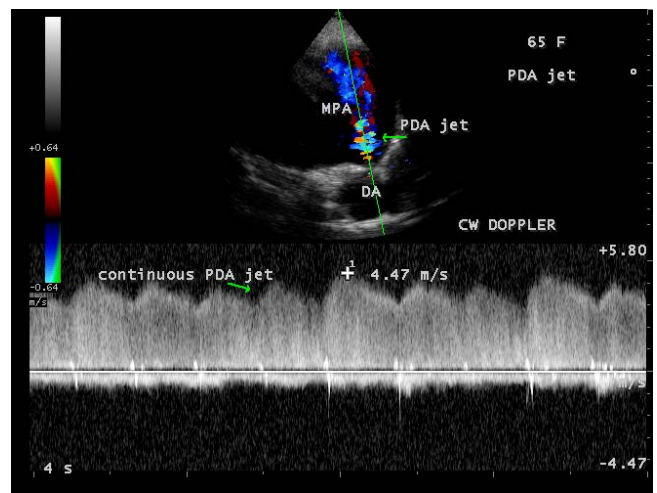

Figure 6. CW (continuous wave) Doppler (green line) showing the "sawtooth" pattern of ductal jet (arrow) in a 65-year-old female. RV systolic pressure (equal to pulmonary artery systolic pressure) is systemic (aortic) systolic pressure $-4 \mathrm{~V}(\mathrm{PDA} \text { jet peak velocity })^{2}=160-4(4.47)^{2}=80$ $\mathrm{mmHg}$ (in case of left-to-right shunt). Patient's systolic blood pressure is $160 \mathrm{mmHg}$ and had severe pulmonary hypertension (normal PA systolic pressure is $15-30 \mathrm{mmHg}$ and peak pressure $>60 \mathrm{mmHg}$ (range 70 to 150 $\mathrm{mmHg}$ ) indicates severe PAH (pulmonary arterial hypertension).

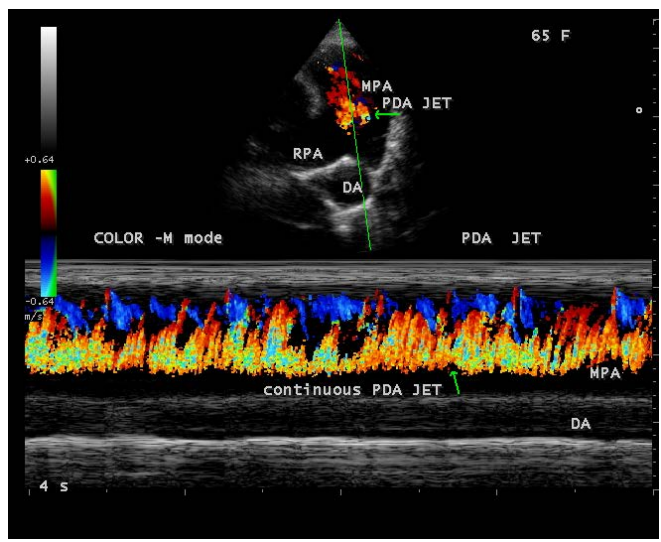

Figure 7. Color M-mode (green line) showing the continuous ductal jet in the main pulmonary artery (MPA) (arrow) in a 65-year-old female. 


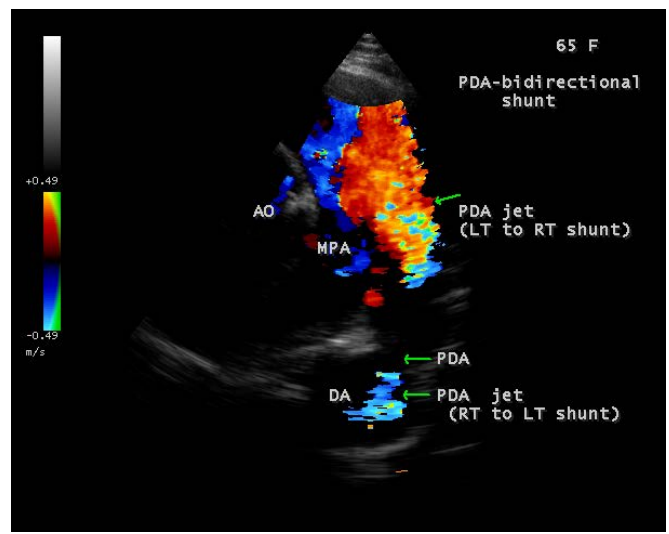

Figure 8. Short axis view showing the bidirectional jet with predominant left-to-right shunting (upper arrow) and a minimal right-to-left shunt (lower arrow) in a 65-year-old female.

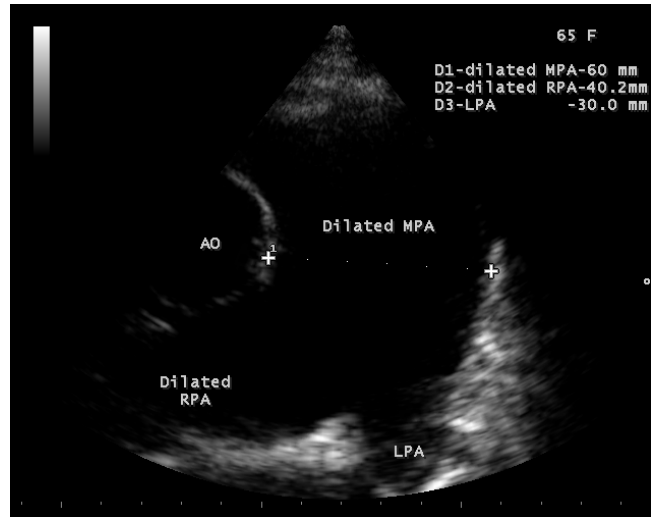

Figure 9. Short axis view showing the enlarged main pulmonary artery (MPA) $(60 \mathrm{~mm})$ and right pulmonary artery $(40.2 \mathrm{~mm})$ as the feature of pulmonary arterial hypertension in a 65 -year-old female.

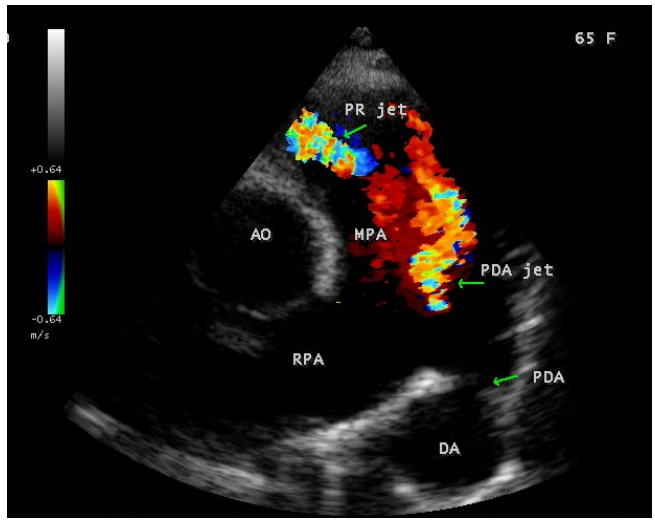

Figure 10. Short axis view showing the pulmonary regurgitation (PR) (upper arrow) as a feature of pulmonary arterial hypertension and ductal (PDA-lower arrow) jets (middle arrow) in a 65-year-old female. 


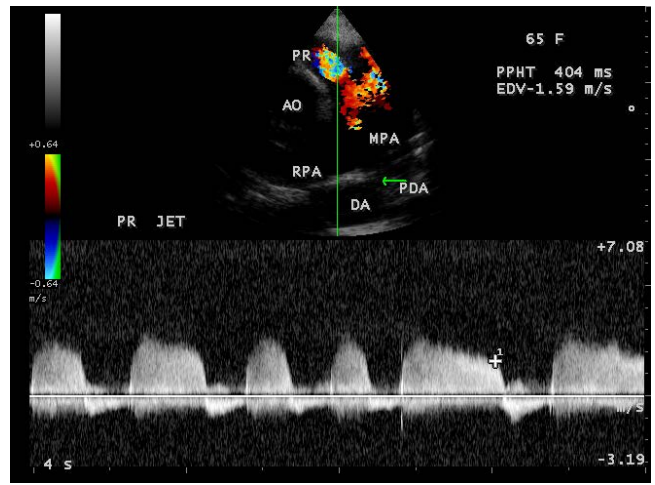

Figure 11. CW (continuous wave) Doppler (green line) showing the pulmonary regurgitation jet in a 65-year-old female. Pulmonary artery end diastolic pressure $=4 \mathrm{~V}^{2}(4 \times 1.59)^{2}=10 \mathrm{mmHg}$ and it is normal (normal range is $4-12 \mathrm{mmHg}$ ) in this patient.

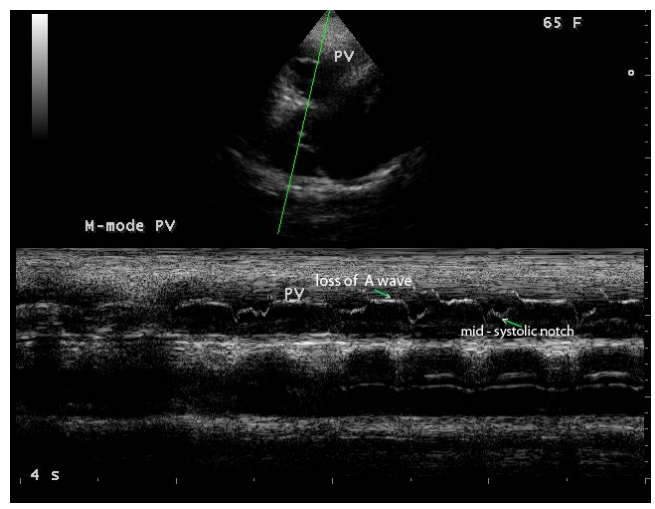

Figure 12. M-mode pulmonary valve (PV) (green line) showing the features of pulmonary arterial hypertension as loss of A wave (upper arrow) and mid-systolic notch (lower arrow) in a 65-year-old female.

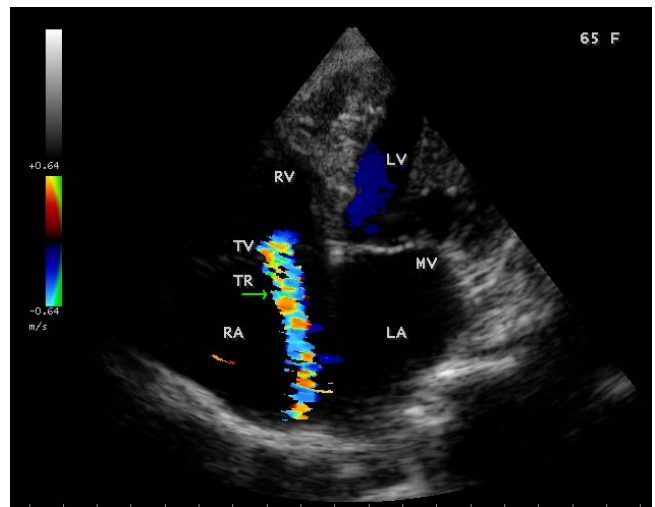

Figure 13. Apical view showing the tricuspid regurgitation (TR) (arrow) in a 65-year-old female due to pulmonary hypertension (secondary TR). 


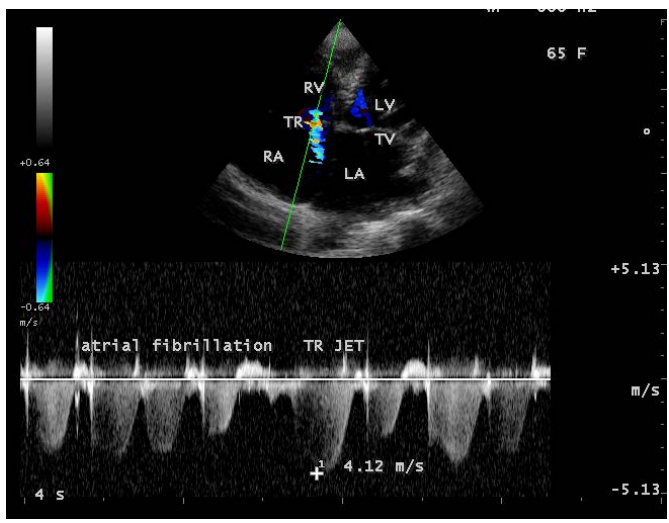

Figure 14. CW (continuous wave) Doppler (green line) showing the tricuspid regurgitation (TR) velocity in a 65 -year-old female. The RV systolic pressure is $4 \mathrm{~V}^{2}(4 \times 4.12)^{2}+\mathrm{RA}$ pressure $(10$ $\mathrm{mmHg})=68+10=78 \mathrm{mmHg}$, which is equal to pulmonary artery systolic pressure.

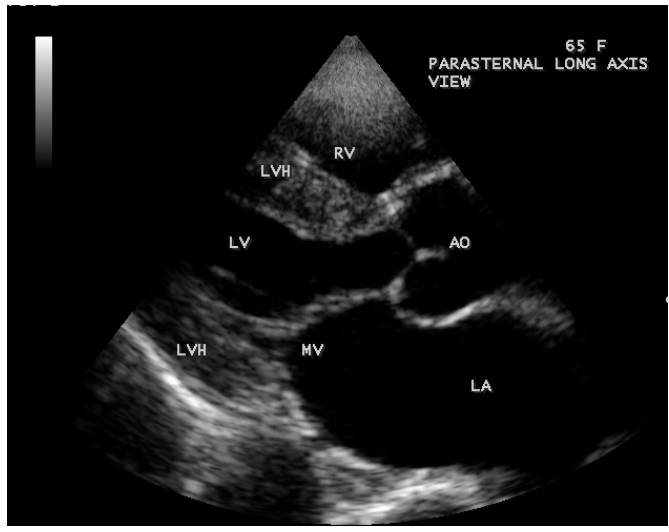

Figure 15. Parasternal long axis view showing the concentric LVH (left ventricular hypertrophy) and LA (left atrial) enlargement in a 65-year-old female.

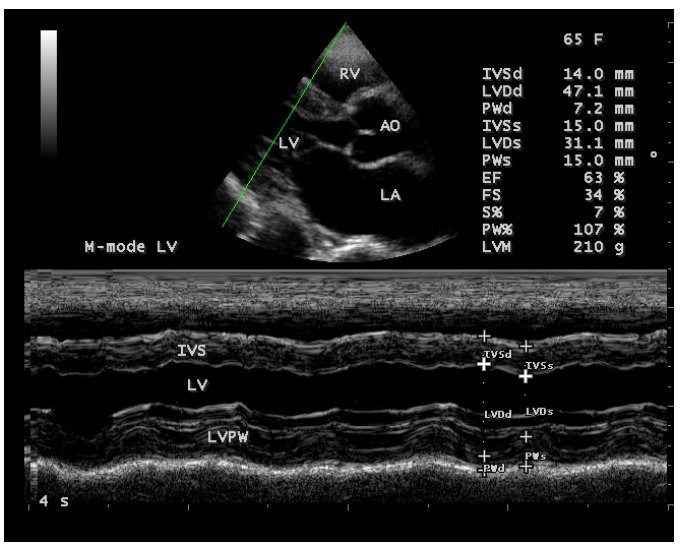

Figure 16. M-mode LV (left ventricular) study (green line) showing normal LV function (EF 63\%) in a 65 -year-old female. 


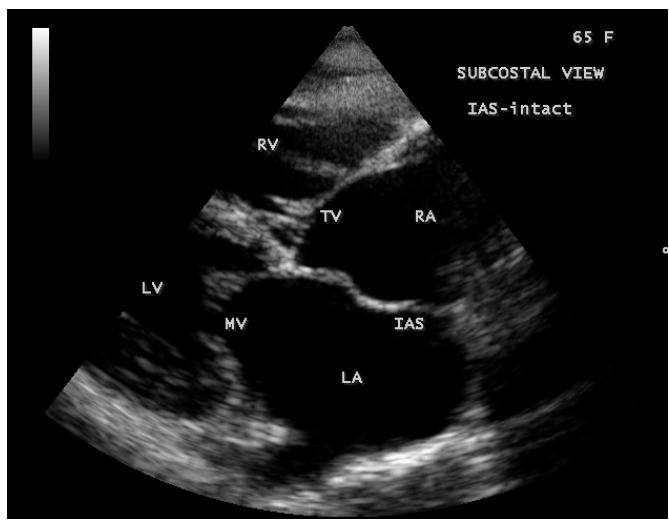

Figure 17. Subcostal view showing the intact IAS (interatrial septum) in a 65-year-old female.

\section{Discussion}

\section{Review of literature}

In 1593, Giambattista Carcano described the ductus arteriosus in his book on the great cardiac vessels of the fetus [18]. Leo Bottali misapplied the term ductus to the foramen ovale and later it was recognized as a specific congenital malformation [19]. In 1924, Holman [20] discussed the presence of right ventricular hypertrophy in isolated patent ductus arteriosus with a possibility of right to left shunt occurring through the ductus. In 1944, Chapman and Robbins reported a very short ductus, $1.2 \mathrm{~cm}$ in diameter [21] with right ventricular and pulmonary artery enlargements, associated cyanosis in 37-year old taxi driver.

\section{Etiopathogenesis}

The ductus arteriosus is a normal and essential fetal structure. The distal portion of the left sixth primitive aortic arch persists embryologically as the ductus arteriosus and it is completely formed by the eight week of gestation. The fetal patent ductus is a major anatomic component of an intrauterine great artery consisting of pulmonary trunk/ductus/aortic continuity that delivers $85 \%$ of right ventricular output into the descending aorta [22]. The ductus arteriosus is patent at birth and appears as a muscular artery with an intact internal elastic lamina. Histologically, the media of the ductus arteriosus is composed of longitudinally and spirally arranged layers of smooth muscle fibers within loose, concentric layers of elastic tissue. The intima is thickened and irregular, with abundant mucoid material, sometimes referred to as intimal cushions, which protrude into the lumen of the mature ductus [23] at term and capable of contraction as functional closure (first stage) which begins within 10 to 15 hours after birth in full term infants, completes by the second week of extrauterine life and followed by anatomic closure (second stage) that first initiated at the pulmonary arterial end [24], usually completed by the 2 to 3 weeks of life due to infolding of endothelium, fragmentation of internal elastic lamina along with subintimal disruption and proliferation, results in fibrosis and permanent seal [25] and persists as 
fibrous band with no lumen to produce the "ligamentum arteriosum". Spontaneous closure is unlikely in premature infants after 1 year of age [26] and in full term infants after 3 months of age [27]. Ductus arteriosus is nourished primarily from the lumen, however, vasavasorum is also a substantial provider to the outer wall of the ductus which extends up to $400-500 \mu \mathrm{m}$ from the outer wall. The distance between the lumen and vasavasorum $(40-500 \mu \mathrm{m})$ is the avascular zone which provides effective nutrient diffusion and in preterm infants, it may not significantly expand, resulting in cell survival and maintenance of ductal patency [28] and in full term infants, it expands and contributing to cell death.

Fetal patency of ductus arteriosus and the ductal tone is contributed by many factors such as low oxygen tension [29] and cycloxygenase products of arachidonic acid metabolism (prostaglandin) $\mathrm{E}_{2}$ and $\mathrm{I}_{2}$ (prostacyclin) [30]. $\mathrm{PGE}_{2}$ is the most profound ductal relaxant [31], [32] among the prostanoids and it activates G-coupled prostaglandin receptor $\mathrm{EP}_{4}$. Following activation, the accumulation of cyclic adenosine monophosphate, increased protein kinase A and finally, decreased myosin light chain kinase, leading to smooth muscle relaxation, vasodilatation and ductal patency [33]. The preterm ductus is sensitive to the vasodilatory effects of both locally producing from the ductal wall and circulating prostaglandins, contributing to the failure of ductal closure [34] and in term infants, this sensitivity decreases leadimg to ductal closure [35] and it is also due to an increase in extrauterine ambient oxygen tension, which exerts a direct constricting effect on the ductal wall, related to inhibition of smooth muscle voltage-gated potassium channels [36], resulting influx of calcium leading to ductal constriction. In the fetus, the circulating $\mathrm{PGE}_{2}$ and $\mathrm{PGI}_{2}$ levels are high because of production by the placenta, decreased metabolism in the fetal lungs and the oxygen induced constriction fails due to immaturity of oxygen -sensing receptors [37]. At birth, circulating levels of prostanoids decreases due to increased metabolism in the newly functioning lungs and the removal of placental sources, leading to smooth muscle constriction with ischemic hypoxia of the inner muscle wall of the ductus as a result of obstructed flow through the vasavasorum nourishing the outer cells of the vessel. Preterm infants are resistant to smooth muscle hypoxia, which is paramount in triggering the cell death and remodeling required for permanent closure of the ductus arteriosus [38] [39].

The factors responsible for permanent patency of the ductus arteriosus beyond the first 24 to 48 hours of neonatal life are not fully understood. Patency of the ductus arteriosus in full-term newborn is a true congenital malformation, probably related to a primary anatomic defect of the elastic tissue within the wall of the ductus. Ontogenic differences in physiologic factors almost certainly account for the higher incidence of persistent patency of the ductus arteriosus in preterm infants [40]. Thus, prematurity increases the incidence of PDA due to physiological factors rather than inherent abnormality of the ductus [41] and in term infants, genetic factors and prenatal infection appear to play a role. Genetic studies suggest the derangements of neural crest cell derivatives [42], [43] as in 
Char syndrome (facial dysmorphism and hand anomalies) and abnormal fibronectin-dependent smooth muscle cell migration. PDA occurs with increased frequency in several genetic syndromes such as in chromosomal aberrations (trisomy 21, 4p-syndrome), single-gene mutations (Carpenter's syndrome, Holt-Oram syndrome), X-linked mutations (incontinenta pigmenti) and in some cases due to autosomal recessive inheritance with incomplete penetrance [44].

Exposure to rubella infection during first trimester of pregnancy, particularly in the first 4 weeks, is associated with high incidence of PDA [45], [46] during later winter and early spring season [47]. Rubella virus interferes with the normal formation of arterial elastic lamina and derivatives of sixth aortic arch. Histologically, there is an extensive subendothelial elastic lamina that is incompatible with anatomic sealing, resulting a very immature ductus. Cardiovascular system is involved in $60 \%$ of cases, PDA accounts for one third of these malformations due to maturational arrest and often associated with rash, deafness, cataracts, peripheral pulmonary arterial stenosis and systemic arterial stenosis, especially of renal arteries.

PDA is about six times as frequent in high altitude as in sea level residents with increased pulmonary vascular resistance as a feature of high altitude birth. [48]. An environmental trigger that occurs at a vulnerable time [49] as in fetal valproate syndrome [50] and the mechanism has not been determined.

The hemodynamic impact of PDA is determined by the magnitude of shunting, which largely depends on the flow resistance in the ductus arteriosus. The ductal flow is dynamic, pulsatile and the elasticity of the ductal wall may affect the impedence to blood flow [51]. The most important physiologic feature is the presence of a marked elevation of pulmonary artery pressure, which may be due to an elevation of total pulmonary blood flow or to an increase in pulmonary vascular resistance. In uncomplicated PDA, there is a linear relationship between pulmonary flow and pressure. In the usual patent ductus, there is a relatively large flow of blood from the aorta to the pulmonary artery ranging from 2 to 10 liters per minute [52] with an increase of total pulmonary blood flow to levels of 6 to 15 liters per minute and there is either a normal or only moderately elevated pulmonary artery pressure, roughly to the magnitude of shunt. The capacity of tolerating large flow with a slight elevation in pressure is a characteristic feature of pulmonary vascular bed and is due to its low resistance. Certain reports of the patency of the ductus arteriosus persisting into old age have indicated no unusual degree of pulmonary hypertension [53] and there is a lack of correlation between pulmonary blood flow and pulmonary artery pressure. The possibility of maladjustment of resistances in the systemic and pulmonary circulations, so that the physiological fall in pulmonary vascular resistance after birth does not occur [54] and an elevation of pulmonary artery pressure leading to organic changes in the pulmonary vascular tree, which operates in some cases of primary pulmonary hypertension in infancy [55], initiated by undetermined factors and 
could well be responsible for most cases of PDA with pulmonary hypertension, which in neonatal life interfere with closure of ductus and it is the cause rather than the result of patency of the ductus. In one instance, the diffuse pulmonary arteritis (healed arteritis) had been demonstrated [56].

If the ductus is large and offers minimal resistance to flow (nonrestrictive), the degree of shunting depend on the status of pulmonary vascular resistance and the left-to-right shunting through PDA has been defined as "dependent shunt" [57] for this reason. The high pressure and increased flow due to long standing left-to-right shunt may cause microvascular injury and that stimulate the production of growth factors and enzymes, causing intimal proliferation, medial hypertrophy [58], endothelial dysfunction and platelet activation, leading to obliteration of pulmonary arterioles [59] and capillaries with a progressive increase in pulmonary vascular resistance (PVR). When PVR approaches and exceeds systemic vascular resistance (SVR), the ductal shunting reverses and becomes right-to-left, leading to cyanosis and "Eisenmenger's syndrome". A dilated hypertensive pulmonary trunk may cause hoarseness by compressing the recurrent laryngeal nerve. Genetic predisposition may play an important role in the phenotypic variability of pulmonary arterial hypertension and the bone morphogenetic protein receptor ${ }_{2}\left(\mathrm{BMPR}_{2}\right)$ mutation was also observed [60]. Eisenmenger's syndrome is a multisystem disorder, presenting with array of potentially life-threatening complications including hyperviscosity, abnormal hemostasis, and arrhythmias. Patients may develop severe calcification of pulmonary artery and ductus as in Figure 2. Calcium appears in the ductus of older patients [61] [62] [63]. Kelly reported that calcium deposits in the ductus arteriosus were common after the age of 30 [64] and in adult series, the incidence was $14 \%$.

\section{Echocardiographic Features}

Echocardiography with color flow imaging and Doppler interrogation remains the gold standard to confirm the diagnosis of PDA [65]. When the shunt is entirely left to right as in Figure 4 and Figure 5, the flow disturbances within the ductus is continuous as in Figure 6 and Figure 7 and the peak velocity reinforced in later systole because forward flow from the right ventricle coincides with shunt flow through the ductus [66],. Color flow pattern in the pulmonary trunk consists of ductal jet that adheres to the lateral wall as in Figure 10 that adheres to the lateral wall, travels towards the pulmonary valve and then reverse itself to travel up the medial wall. Sometimes, a jet directed towards the pulmonary valve adheres to the medial wall of the pulmonary trunk. Right ventricular pressure and pulmonary artery diastolic pressure can be estimated by continuous wave Doppler interrogation of the jet of tricuspid as in Figure 13 and Figure 14 and pulmonary regurgitation as in Figures 10 and Figure 11 and by Doppler velocities across the ductus [67] as in Figure 6. A complete pulmonary artery pressure curve can be generated from the spectral Doppler signal of ductal flow. The RV (right ventricular) systolic pressure (equal to pulmonary artery 
systolic pressure), calculated by ductal jet velocity ( $80 \mathrm{mmHg}$ as in Figure 6) and TR (tricuspid regurgitation) jet velocity $(78 \mathrm{mmHg}$ as in Figure 14) is more or less same in this patient.

M-mode echocardiogram of pulmonary valve with features of loss of pulmonic A-wave and mid-systolic notching suggest pulmonary hypertension [68] as shown in Figure 12 and pulmonary artery and its branches, especially the right pulmonary artery are grossly dilated as in Figure 2 and Figure 9. Bidirectional shunting may be present with predominant left-to-right shunting as in Figure 8 until the pulmonary vascular resistance is severe enough to cause right-to-left shunt alone. Left ventricular hypertrophy $\{\mathrm{LVH})$ is a feature of predominant left-to-right shunt as in Figure 15 and the left ventricular function is preserved as in Figure 16. There are no echo drop-outs across the interatrial septum (IAS) as in Figure 17.

\section{Management}

Optimally, treatment should be aimed directly at removing the shunt and its effects by closure of the ductus arteriosus. However, ductus arteriosus is a unique structure after birth because its patency on one hand results in cardiac decompensation but may on the other hand only life-sustaining conduit to preserve systemic or pulmonary arterial blood flow in the presence of certain cardiac malformations such as right (pulmonary atresia-PDA is the only source of pulmonary arterial blood flow) or left ventricular outflow tract obstructive lesions (aortic atresia, aortic arch interruption, hypoplastic left heart syndrome-PDA is the only source of systemic arterial blood flow) or PDA is the only source of bidirectional blood flow in isolated complete transposition of great arteries.

Patent ductus arteriosus can be treated either by pharmacologic obliteration or surgical interruption.

Medical therapy

Asymptomatic child with PDA and normal heart size on chest X-ray is to be treated medically.

Conservative approach

In treating a premature infant with a PDA, maintenance of an adequate hematocrit above $45 \%$ and hemoglobin is essential. Diuretics may be useful if the neonate has signs of heart failure with significant left-to-right shunt in the first 4 to 6 weeks of life as the result of normal fall in pulmonary vascular resistance after birth while waiting for the spontaneous closure of the ductus. The loop diuretic furosemide may contribute the patency of ductus arteriosus through the stimulation of renal $\mathrm{PGE}_{2}$ [69]. Digitalis is rarely used now for the treatment of left ventricular failure due to potential toxic reactions and relatively ineffective in very small preterm infants due to altered myocardial structure with fewer contractile elements, incomplete sympathetic innervations of left ventricular myocardium, less to stretch (Frank-Starling mechanism) and lower than normal serum calcium concentration contributing to early development of left ventricu- 
lar failure in preterm infants.

A "watch-and-wait" approach may be adapted since approximately $34 \%$ of extremely low birth weight preterm infants $(<1 \mathrm{~kg})$ with gestational age $26 \pm 2$ weeks with a PDA demonstrated spontaneous closure at $4.3 \pm 2$ days postnatal age in a recent study by Koch, et al. [70]. In others, spontaneous closure occurs at a rate of $0.6 \%$ per year.

COX inhibitors

Nonselective COX (cycloxygenase) inhibitors are the treatment of choice for pharmacologic closure of PDA. Although $\mathrm{COX}_{2}$ is intrinsic to ductus arteriosus, $\mathrm{PGE}_{2}$ derived from $\mathrm{COX}_{1}$, formed intramurally in the ductus and exerts its action locally on muscle cells. $\mathrm{PGE}_{1}$ is currently used as pharmacologic prevention of ductal closure and it dilates the ductus with a marked improvement in systemic oxygenation and renal function with reversal of acidemia in ductus-dependent lesions [71], especially in juxtaductal coarctation in which sudden occurrence of acute left ventricular failure, produced by the rapid constriction of the ductus in postnatal period. The timing of therapy is important since the responsiveness to $\mathrm{PGE}_{2}$ decreases with increased age and so delaying treatment may result in diminished efficacy of COX inhibitors.

Currently, there are two FDA (Food and Drug Administration) approved COX inhibitors are indicated in the closure of PDA.

Indomethacin

The use of oral or, preferably intravenous (IV) indomethacin to constrict the ductus is a nonsurgical closure in a large population of treated infants [72]. In premature infants, treatment with indomethacin is usually the first-line therapy, however, it has been associated with an increased bleeding tendency resulting from platelet dysfunction, decreased urinary output secondary to renal dysfunction and necrotizing enterocolitis. Indomethacin should not be administered when serum creatinine $>1.6 \mathrm{mg} / \mathrm{dl}$ or blood urea nitrogen $>20 \mathrm{mg} / \mathrm{dl}$ and if there is ECG evidence of myocardial ischemia [73]. It has been used with good success, particularly in infants with birth weight $<1000$ grams, but reopening of the ductus still occurs frequently and the functionally closed ductus may dilate with a reduced arterial blood $\mathrm{Po}_{2}$ or increased $\mathrm{PGE}_{2}$ concentration before true anatomic closure occurs. Indomethacin can be given with an initial dose of 0.2 $\mathrm{mg} / \mathrm{kg}$ by nasogastric or intravenously (lyophylised) and subsequent two doses $0.10 \mathrm{mg} / \mathrm{kg}$ if the age is $<48$ hours, $0.20 \mathrm{mg} / \mathrm{kg}$ if the age is 2 to 7 days, 0.25 $\mathrm{mg} / \mathrm{kg}$ if the age is $>7$ days at 12 to 24 hours apart depending on the urinary output. Indomethacin is ineffective in term infants and older children and therefore should not be given and the effects of indomethacin apparently are best before ten days of age and in less mature infants.

The ductus will reopen in up to $35 \%$ of infants who initially respond to the drug and a more prolonged course of indomethacin ( 6 to 8 doses- -0.6 to 1.6 $\mathrm{mg} / \mathrm{kg}$ ) has been studied to achieve higher rate of ductal closure. Prolonged course compared to the short course ( 2 to 3 doses -0.3 to $0.6 \mathrm{mg} / \mathrm{kg}$ ) did not reduce the rate of PDA reopening after the initial closure and it is associated 
with decreased incidence of renal dysfunction [74], but increases the risk of NEC (necrotizing enterocolitis).

Ibuprofen

Ibuprofen has achieved closure rates of $75 \%$ - 93\% equivalent to that of indomethacin with less renal toxicity and less significant impact on cerebral and mesenteric blood flow. Ibuprofen trishydroxyaminomethane (THAM) is the intravenous formulation currently available in Europe. Oral route is not optimal due to impaired absorption of poorly perfused gastrointestinal tract. In low resource countries such as Jordan, many studies have shown that oral ibuprofen is both safe and effective in treating PDA [75] and also rectal forms of ibuprofen has been investigated [76].

Paracetamol

Paracetamol inhibits prostaglandin synthetase activity by acting at the peroxidase segment of the enzyme. In hypoxemia, peroxidase concentration decreases, paracetamol is more effective than cycloxygenase inhibitors and it is also the only option when there is a contraindication for ibuprofen use [77]. Oral paracetamol is a safe and readily available medication that is much less expensive than intravenous preparation. The role of intravenous paracetamol as a late medical therapy of PDA closure (27 days after birth) has been also evaluated recently [78].

Pulmonary vasodilators

Patients with PDA and pulmonary vascular disease who are considered unacceptable candidates for definitive closure, may be managed with specific therapies targeted on the major pathways (endothelin, nitric oxide, prostacyclin) identified in its pathophysiology, which include pulmonary vasodilators, endothelin receptor antagonists and phosphodiesterase type $\mathrm{V}$ inhibitors.

Endothelin receptor antagonists

Bosentan, macitentan (both affect A and B receptors) and ambrisentan (selective for A receptor) have been studied, but majority of patients discontinued therapy due to side effects. Interestingly, a recent trial showed an improved outcome with macitentan, but there is no difference in occurrence of syncope and heart failure events following therapy [79].

Phosphodiesterase-5 inhibitors (PDE-5i)

The sildenafil treatment (once daily) for 12 weeks led an increase in exercise capacity and improvement in hemodynamics [80] and similar favourable results with tadolafil in pulmonary arterial hypertension. Addition of oral sildenafil after transcatheter ductal closure resulted an improvement in right heart function over time.

Drugs on nitric oxide pathway

The soluble guanylate cyclase stimulation with riociguat [81] is under trial for the treatment of pulmonary arterial hypertension.

Prostacyclin analogs

Intravenous (IV) prostacyclin analog is the first pulmonary vasodilator used 
in Eisenmenger's syndrome. Eg. IV Epoprostenol. Treprostinil (oral or inhaled) or subcutaneous route is enrolled to minimize the risks of paradoxical embolism and line sepsis.

In general, oral therapies are preferred and recently, selexipag [82], the first oral selective non-prostanoid IP-receptor agonist was approved for the treatment of pulmonary arterial hypertension. However, more data are needed for these advanced therapies either to use as a monotherapy or in combination.

Newer candidate therapies are focused on metabolic, inflammatory and regenerative alternate pathways. L-citrulline (NO-independent stimulator), imatinib (a selective antagonist of platelet-derived growth factor receptor) seemed to be effective in patients with severe or drug-refractory pulmonary arterial hypertension, but its clinical use is questionable due to serious side effects. Competitive reversible protease inhibitor (ubenimex), oral selective IP-receptor agonist (ralinepag), inhaled prostacyclin receptor agonist QCC374, and autologous progenitor cell-based therapy are under studies in the treatment of pulmonary arterial hypertension.

During Pregnancy

Left-to-right shunt through PDA increases in pregnancy due to a decrease in PVR (pulmonary vascular resistance). Maternal mortality in Eisenmenger's syndrome is high $(30 \%$ to $50 \%)$ and so pregnancy is contraindicated. The greatest risk of death is in the postpartum period and beyond 6 weeks after delivery. In the current era, outcome has been improved with the use of pulmonary vasodilators and pulmonary vascular remodeling agents. Endothelin receptor antagonists are teratogenic and prohibited in pregnancy. Both nebulized and intravenous ilioprost (a prostacyclin analog) have been used safely [83]. Phosphodiesterase-5 inhibitors are also effective. More intensive parenteral or subcutaneous infusion with prostacyclin can be used during pregnancy to decrease RV failure. Iron supplementation, diuretics such as furosemide may be helpful if there is signs of heart failure with elevated JVP (Jugular venous pressure), but spironolactone is contraindicated due to its antiandrogenic effect. Inhaled nitric oxide can decrease the pulmonary arterial resistance. Oxytocic drugs may have harmful effects and should be avoided. Delivery by Cesaerian is preferred with the use of regional anesthesia (epidural) and single dose spinal anesthesia must be avoided because of the risk of hypotension. Anticoagulants are indicated in postpartum period to reduce the risk of thromboembolic episodes.

In adult PDA, heart failure is frequently associated with atrial flutter or fibrillation and anticoagulants are indicated [84].

Definitive Therapy (Ductal closure)

Primary closure of the PDA is an attractive therapy in salvaging the pulmonary vascular bed. Ductal closure is indicated in the absence of severe pulmonary vascular disease with predominant right-to-left shunting. PVR (pulmonary vascular resistance) $>6 \mathrm{U} / \mathrm{m}^{2}$, at best, poor candidates for intervention. In presence of large PDA with pulmonary hypertension, a combined medical and interventional therapy as a "staged" paradigm approach has been described. Neoadjuvant 
pulmonary vasodilator therapy with secondary repair of shunt when PVR drops to acceptable level, the so-called "treat-and-repair" strategy as a bridge to PDA closure in this challenging population is helpful.

Transcatheter closure

Transcatheter closure of PDA, using various approaches, including coils, buttons, plugs, and umbrellas are common and it is feasible in those weigh $>10 \mathrm{~kg}$.

Transcatheter, non surgical closure of PDA using a conical Ivalon plug was introduced by Porstmann and colleagues in 1967 [85]. Rashkind developed a polyurethane foam disc double umbrella device in 1979 [86]. These devices are rather large, requiring large introducer sheath, inapplicable to young and very small children and frequently leaving residual shunting. Cambier, et al. in 1992 [87] reported the use of Gianturco coils (free and detachable) for transcathter closure of PDA, which became a widely used technique for the closure of small to moderate ducts and it can be delivered through small catheter and useful in those younger than 8 months of age. Gianturco coils occasionally migrate or assume unacceptable position. Detachable coils are now readily available, which allow the assessment of adequate positioning before release. Nit-Occlud coil [88] has a biconical shape that is more suitable for the conical shape of most ductus than the cylindrical Gianturco coils. Catheter closure with occluding coils has been the treatment of choice for all children more than few months of age with ductus $<5$ to $6 \mathrm{~mm}$ diameter. An occluding coil is placed in the PDA with a single coil loop on the pulmonary artery side and the remaining 3 to 4 loops in the ductal ampulla. Occasionally, immediate placement of a second coil is needed to achieve complete closure. This procedure is over $97 \%$ successful with zero mortality and no significant morbidity. Specialized devices are currently being developed to improve the efficacy of transcatheter therapy for children with PDA larger than $6 \mathrm{~mm}$ or for infants. Thus, the efficacy and safety of transcatheter closure for the ducts $<8 \mathrm{~mm}$ has been established. The diameter of ductus arteriosus must be smaller than that of femoral artery. The duct size was described according to the diameter at the pulmonary end. The device chosen for closure was $4 \mathrm{~mm}$ larger than duct diameter to prevent embolization and to reduce the residual shunt. At present, thrombogenic coils are used to treat a small ductus and an Amplatzer occluder for a ductus larger than $3 \mathrm{~mm}$. In patients with "filiform" PDA, the procedure failed because the diameter did not allow catheter advancement to implant a coil.

The Amplatzer Duct Occluder [89] is frequently used for larger type B (short) ductus and it is made of Nitilon wire woven into a mesh in the configuration of a mushroom-shaped plug and it has a detachable cable which allows easy repositioning or retrieval if necessary. The Amplatzer ASD sizing balloon $(24 \mathrm{~mm})$ can be used for dynamic sizing. The balloon pull-through technique for PDA size is safe in adults using transcatheter PDA closure. The Amplatzer duct occluder (ADO) has been modified such that the retention skirt has an angle and concavity that allows it to fill better at the aortic end and other devices currently in use are "modified folding-plug button device" and the "wireless patch" developed by 
Sideris and associates.

Adult PDA

In case of calcified ductus with increased pulmonary vascular resistance, transcatheter closure offers considerable advantages over surgical closure. Even though transcatheter coil embolization was used in children with small PDAs, coil embolization with detachable coils can be used in adults, who have heart failure due to large PDA [90] since PDA in adults is often calcified with degenerative changes and successful surgical closure is risky in this situation. In case of hemolysis related to residual shunt, a second coil embolization may eliminate it.

Amplatzer muscular VSD occluder (septal) is preferred for closing larger PDAs with pulmonary arterial hypertension. Pulmonary vascular disease characterized by histological changes consistent with severe, irreversible pulmonary vascular involvement may completely resolve after closure of PDA. Reactivity of pulmonary vascular bed to pulmonary vasodilating agents and/or significant reduction of pulmonary artery pressure and resistance during test occlusion [91] may offer reassurance with regard to reversibility, but the absence of such evidence does not exclude the possibility of reversibility in the long term. Closing the PDA without test occlusion is at a risk of right heart failure and hemodynamic collapse. A balloon catheter is used tentatively to occlude the patent duct before deciding whether to permanently implant the Amplatzer occluder to differentiate kinetic pulmonary hypertension from obstructive. If the main pulmonary artery pressure falls $>1 / 5^{\text {th }}$ or $20 \mathrm{mmHg}$ and systemic arterial pressure did not decline, then kinetic pulmonary hypertension and reversible pulmonary vascular disease is concluded and Amplatzer occluder device can be implanted permanently and there are only few reports on transcatheter closure of PDA with severe pulmonary hypertension (PVR $>8$ Wood units) in adults. A slight decrease in pulmonary artery pressure is due to pulmonary vascular spasm. When main pulmonary artery pressure rise and systemic arterial pressure falls, then obstructive and irreversible pulmonary vascular disease is diagnosed and closure may precipitate acute elevation of pulmonary artery pressure, pulmonary hypertensive crisis and acute right heart failure.

Surgical closure

Surgical ligation or division of the PDA remains the treatment of choice for the rare very large ductus and should be reserved for ductus $>8 \mathrm{~mm}$ in diameter. When signs of necrotizing enterocolitis (persistent abdominal distension due to bowel ischemia) in an infant with significant left-to-right shunting through a PDA, early surgical closure has significantly reduce the mortality. If left ventricular failure is uncontrolled within 48 to 72 hours of adequate medical management, surgical closure is preferred. Despite the small risk of recannalization, ligation rather than division is recommended because the tissues in premature infants are very friable.

The operative technique of ductal ligation was described in 1907 by Munro [92]. Gross and Hubbard reported the first successful ligation of PDA at Bosten 
Children's hospital in 1939 [93]. One point that merit special attention is the frequent occurrence of gastric distension after PDA ligation and it is due to traction on vagus nerve and some degree of gastroparesis, which is managed with avoidance of oral intake in the first post operative day, nasogastric intubation and decompression. Surgical ligation is associated with increased risk of bronchopulmonary dysplasia, neurosensory impairement, and severe retinopathy of prematurity. Unlike pharmacologic closure, surgical ligation has not been shown any benefit on alveolar growth.

Reports of recurrent ductal patency due to recannalization with current surgical methods is ranging from $0.4 \%$ to $3 \%$. Results after the classic duct surgical approach have been very good and the surgical risk in children with isolated $\mathrm{Pa}$ tent Ductus Arteriosus is $<0.5 \%$. Excellent results have been obtained even in premature age group. The fragile, thin, useless PDA of a premature infant is obliterated by gentle ligation with a thick suture to minimize disruption or, if small, by occlusion using metallic surgical clips. Ductus obliteration offers clinical improvement in infants weighing as little as $500 \mathrm{~g}$ with minimal operative risk. Rarely, a large window type PDA may have insufficient length to permit ligation, and the appropriate surgical procedure is patch closure on cardiopulmonary bypass.

Adult PDA

Adult patients with PDA should be treated surgically if cardiomegaly is seen at initial presentation to prevent the increase in heart size, elevation of pulmonary artery pressure (without apparent Eisenmenger physiology) and further clinical deterioration and it is recommended when there is no right-to-left shunt. Surgical closure of PDA in adults involves a number of risks, associated with anatomic and histologic changes in the duct, including, calcification, aneurysm, diverticulum, shortening, friability and rarely rupture The calcification and rigidity of the ductal wall may complicate clamping. Placement of a Dacron patch over the aortic orifice of the ductus from within the aorta may be advisable. Division and suture of the ductus with aortic cross clamping under normothermic conditions provide excellent long-term survival in surgically treated patients and no deaths in patients with pulmonary arterial pressure $<70 \mathrm{mmHg}$. However, on aortic cross clamping, if pulmonary artery pressure rises and systemic pressure falls, the surgical closure should be avoided. Surgical closure using a pursestring suture around the orifice of the ductus allows minimization of the risk of balloon breakage. The only contraindication to surgical closure of an isolated PDA is severe pulmonary hypertension with irreversible pulmonary vascular disease or bidirectional shunt with predominant right-to-left identified by Echo-Doppler.

Wright technique

A double or triple ligation on Teflon strips as described by Wright is the first surgical option for the treatment of PDA in adults and it is the most frequently used technique (69\%) with good results in Africa where open heart surgeries are 
not carried out [94]. This technique is preferred when there is no high systemic arterial pressure and a normal or moderately high pulmonary pressure [95].

The indication for closure of tiny, incidentally discovered "silent" ductus by Doppler is uncertain and in older adults, endarteritis has been reported. Infective endarteritis in restrictive PDA is due to high velocity left-to-right shunt and not occurs in nonrestrictive and reversed shunt.

\section{Outcome}

In patients with isolated, uncomplicated PDA, the life expectancy should be near normal. The clinical manifestations of PDA may vary greatly among people. Some may develop heart failure in $3^{\text {rd }}$ decade and others become manifest when acquired conditions such as recurrent pneumonia and chronic obstructive pulmonary disease occurs. The improved survival results from the preservation of RV function by the prevention of remodeling during infancy, the RV remain hypertrophied and more likely to be the fetal heart than the normal adult in Eisenmenger heart [96]. The pulmonary artery may approach aneurysmal size, up to $60 \mathrm{~mm}$ in this patient due to constant "jet stream" impact. A pulmonary artery diameter of $>48 \mathrm{~mm}$ (normal $-27 \mathrm{~mm}$, the range is $19.5 \mathrm{~mm}$ to 32.6 $\mathrm{mm}$ for women) is an independent risk factor for unexpected death in patients with pulmonary arterial hypertension. Extrinsic compression of left main coronary artery (LMCA) is well documented in patients with dilated PA (pulmonary artery) with an incidence as high as $19 \%$ to $44 \%$ and it can be managed with aggressive treatment of PAH (pulmonary arterial hypertension) and stenting of LMCA.

Surgical survival rate was significantly better than the medical survival in the nonsurgical group (93\% versus 83\%]. There are no studies at present showing whether PA diameter decreases with treating of PH (pulmonary hypertension) or if a smaller diameter after treatment correlates with improved morbidity and mortality [97].

A reduction of systolic pressure with amlodipine reduces the left-to-right shunt and the pulmonary vasodilator, sildenafil reduces the PA pressure and a reduction in right-to-left shunt. The patient became symptom free due to this balancing action on both systemic and pulmonary circulations with a relief from pulmonary congestion by diuretic therapy, the furosemide.

Case analysis

A 65 years old female was presented with features of heart failure, chronic obstructive pulmonary disease of short duration and atrial fibrillation. Dilated pulmonary arteries as revealed by X-ray chest and Echocardiography, suggest pulmonary arterial hypertension due to left-to-right shunt through PDA. The detection of PDA at this age group is a rarest one which may be due to high tolerance of pulmonary vascular bed and a persistence of fetal type of heart from infancy as a cause of pulmonary hypertension. The patient was acyanotic since the shunt is predominantly left-to-right even though it is bidirectional with a minimal right-to-left shunting. Transcatheter closure is advisable because of 
predominant left-to-right shunt with calcified pulmonary arteries rather than surgical closure, but conservative management is preferred in this case because of advanced age and improvement of symptoms with medical therapy.

On follow-up, the patient is still alive and symptom-free on continuation of medications.

\section{Conclusions}

Sometimes, patent ductus arteriosus remains asymptomatic until adulthood when pulmonary arterial hypertension or congestive heart failure develops. The majority of long-lived patients with PDA, relatively small left-to-right shunt, the so-called obstructive ductus, do not overload the pulmonary vascular tree and the ductus in such cases may be serving as a the "safety valve", keeping the pulmonary artery pressure from rising to excessive levels during exercise. The mortality rate in adults with untreated PDA has been estimated to be $1.8 \%$ per year [98]. Campbell reported a greater longevity in untreated PDA, with $60 \%$ surviving to the age of 60 years and $4 \%$ per year attrition rate from $4^{\text {th }}$ decade onwards and this patient lived up to the age of 65 years.

In patients with severe pulmonary hypertension, negative occlusion and hyperoxygenation tests indicate that the ductal closure was considered contraindicated and current articles on the use of pulmonary vasodilator medications report encouraging results in such cases.

\section{References}

[1] Dice, J.E., Pharm, D. and Jatinder, B. (2007) Patent Ductus Arteriosus: An Overview. The Journal of Pediatric Pharmacology and Therapeutics, 12, 138-146.

[2] Cassels, D.E., Bharati, S. and Lev, M. (1975) The Natural History of the Ductus Arteriosus in Association with Other Congenital Heart Defects. Perspectives in Biology and Medicine, 18, 541-572. https://doi.org/10.1353/pbm.1975.0061

[3] Schneider, D.J. and Moore, J.W. (2006) Patent Ductus Arteriosus. Circulation, 114, 1873-1882. https://doi.org/10.1161/CIRCULATIONAHA.105.592063

[4] Camphell, M. (1968) Natural History of Patent Ductus Arteriosus. British Heart Journal, 30, 4. https://doi.org/10.1136/hrt.30.1.4

[5] Ng, A.S., Vlietstra, R.E., Danielson, G.K., Smith, H.C. and Puga, F.J. (1986) Patent Ductus Arteriosus in Patients More than 50 Years Old. International Journal of Cardiology, 11, 277-285. https://doi.org/10.1016/0167-5273(86)90032-X

[6] Krichenko, A., Benson, L., Burrows, P., et al. (1989) Angiographic Classification of the Isolated Persistently Patent Ductus Arteriosus and Implications for Percutaneous Catheter Occlusion. American Journal of Cardiology, 63, 877-879. https://doi.org/10.1016/0002-9149(89)90064-7

[7] Mogra, R. and Franzcog, C. (2013) Simplifying Ultrasound Assessment of the Fetal Heart: Incorporating the Complete Three Vessel View into Routine Screening. Australasian Journal of Ultrasound in Medicine, 16, 168-175. https://doi.org/10.1002/j.2205-0140.2013.tb00243.x

[8] Houston, A.B., Gnanapragasam, J.P., Lim, M.K., et al. (1991) Doppler Ultrasound and the Silent Ductus Arteriosus. British Heart Journal, 65, 97-99. 
https://doi.org/10.1136/hrt.65.2.97

[9] Camphell, M. (1955) Patent Ductus Arteriosus: Some Notes on Prognosis and on Pulmonary Hypertension. British Heart Journal, 17, 511-533. https://doi.org/10.1136/hrt.17.4.511

[10] Bain, C.W.C. (1957) Longevity in Patent Ductus Arteriosus. British Heart Journal, 19, 574-576. https://doi.org/10.1136/hrt.19.4.574

[11] Hornstein, T.R., Hellerstein, H.K. and Ankeney, J.L. (1967) Patent Ductus Arteriosus in a 72-Year Old Woman. Journal of American Medical Association, 199, 580-582. https://doi.org/10.1001/jama.1967.03120080114026

[12] White, P.D., Mazurkie, S.J. and Boschetti, A.E. (1969) Patency of the Ductus Arteriosus at 90. New England Journal of Medicine, 280, 146-147. https://doi.org/10.1056/NEJM196901162800306

[13] Hubbard, T.F. and Neis, D.D. (1960) The Sounds at the Base of the Heart in Cases of Patent Ductus Arteriosus. American Heart Journal, 59, 807-815. https://doi.org/10.1016/0002-8703(60)90405-1

[14] Kohler, C.M. and McNamara, D.G. (1967) Elongated Patent Ductus Arteriosus with Intermittent Shunting. Pediatrics, 39, 446-448.

[15] Shapiro, W., Said, S.I. and Nova, P.L. (1960) Intermittent Disappearance of the Murmur of Patent Ductus Arteriosus. Circulation, 22, 226-231. https://doi.org/10.1161/01.CIR.22.2.226

[16] Keith, T.R. and Sagarminaga, J. (1961) Spontaneously Disappearing Murmur of Patent Ductus Arteriosus: A Case Report. Circulation, 24, 1235-1238. https://doi.org/10.1161/01.CIR.24.5.1235

[17] Umebayashi, Y., Taira, A., Morishita, Y. and Arikawa, K. (1989) Abrupt Onset of Patent Ductus Arteriosus in a 55-Year-Old Man. American Heart Journal, 118, 1067-1069. https://doi.org/10.1016/0002-8703(89)90250-0

[18] Castiglioni, A. (1947) A History of Medicine. Alfred A. Knopl, New York.

[19] Marquis, R.M. (1980) The Continuous Murmur of Persistence of the Ductus Arteriosus. A Historical Review. European Heart Journal, 1, 465-478. https://doi.org/10.1093/oxfordjournals.eurheartj.a061149

[20] Holman, E. (1925) Certain Types of Congenital Heart Disease Interpreted as Intracardiac Arteriovenous and Veno-Arterial Fistulae, I. Patent Ductus Arteriosus. Bulletin of the Johns Hopkins Hospital, 36, 61.

[21] Chapman, C. and Robbins, S. (1944) Patent Ductus Arteriosus with Pulmonary Vascular Sclerosis and Cyanosis. Annals of Internal Medicine, 21, 312. https://doi.org/10.7326/0003-4819-21-2-312

[22] Mahoney, L.T., Coryell, K.G. and Lauer, R.M. (1985) The Newborn Transitional Circulation. Two-Dimensional Doppler Echocardiographic Study. Journal of American College of Cardiology, 6, 623-629. https://doi.org/10.1016/S0735-1097(85)80123-6

[23] Gittenberger-De Groot, A.C. and Strengers, J.L.M. (1988) Histopathology of the Arterial Duct (Ductus Arteriosus) with and without Treatment with Prostaglandin $\mathrm{E}_{1}$. International Journal of Cardiology, 19, 153-166. https://doi.org/10.1016/0167-5273(88)90076-9

[24] Gittenberger-DeGroot, A.C., Strengers, J.L.M., Mentink, M., Poelmann, R.E. and Patterson, D.E. (1985) Histologic Studies on Normal and Persistent Ductus Arteriosus in the Dog. Journal of American College of Cardiology, 6, 394-404. https://doi.org/10.1016/S0735-1097(85)80178-9 
[25] Fay, F.S. and Kooke, P.H. (1972) Guinea Pig Ductus Arteriosus, II: Irreversible Closure after Birth. American Journal of Physiology, 222, 841-849. https://doi.org/10.1152/ajplegacy.1972.222.4.841

[26] Gittenberger-De Groot, A.C., Moulaert, A.J.M. and Hitchcock, J.F. (1980) Histology of the Persistent Ductus Arteriosus in Cases of Congenital Rubella. Circulation, 62, 183-186. https://doi.org/10.1161/01.CIR.62.1.183

[27] Gittenberger-De Groot, A.C. (1977) Persistent Ductus Arteriosus: Most Probably a Primary Congenital Malformation. British Heart Journal, 39, 610-618. https://doi.org/10.1136/hrt.39.6.610

[28] Clyman, R.I., Chan, C.Y., Mauray, F., et al. (1999) Permanent Anatomic Closure of the Ductus Arteriosus in Newborn Baboons: The Roles of Postnatal Constriction, Hypoxia, and Gestation. Pediatric Research, 45, 19-29. https://doi.org/10.1203/00006450-199901000-00005

[29] Heymann, M.A. and Rudolf, A.M. (1975) Control of the Ductus Arteriosus. Physiological Reviews, 55, 62-78. https://doi.org/10.1152/physrev.1975.55.1.62

[30] Coceani, F. and Olley, P.M. (1973) The Response of the Ductus Arteriosus to Prostaglandins. Canadian Journal of Physiology and Pharmacology, 51, 220-225. https://doi.org/10.1139/y73-031

[31] Hermes-DeSantis, E.R. and Clyman, R.I. (2006) Patent Ductus Arteriosus: Pathophysiology and Management. Journal of Perinatology, 26, S14-S18. https://doi.org/10.1038/sj.jp.7211465

[32] VanOvermeire, B. and Chemtob, S. (2005) The Pharmacologic Closure of the Patent Ductus Arteriosus. Seminars in Fetal and Neonatal Medicine, 10, 177-184. https://doi.org/10.1016/j.siny.2004.10.003

[33] Ivey, K.N. and Srivastava, D. (2006) The Paradoxical Patent Ductus Arteriosus. Journal of Clinical Investigation, 166, 2863-2866. https://doi.org/10.1172/JCI30349

[34] Clyman, R.I., Camphell, D., Heymann, M.A., et al. (1985) Persistent Responsiveness of the Neonatal Ductus Arteriosus in Immature Lambs: A Possible Cause for Reopening of Patent Ductus Arteriosus after Indomethacin-Induced Closure. Circulation, 71, 141-145. https://doi.org/10.1161/01.CIR.71.1.141

[35] Clyman, R.I., Mauray, F., Rudolpf, A.M., et al. (1980) Age Dependant Sensitivity of the Lamb Ductus Arteriosus to Indomethacin and Prostaglandins. Circulation, 93, 94-98.

[36] Michelakis, E., Rebeyka, I., Bateson, J., Olley, P., Puttagunta, I. and Archer, S. (2000) Voltage-Gated Potassium Channels in Human Ductus Arteriosus. The Lancet, 356, 134-137. https://doi.org/10.1016/S0140-6736(00)02452-1

[37] Bernard, T., Michelakis, E.D., Wu, X., et al. (2004) Oxygen-Sensitive Kv Channel Gene Transfer Confers Oxygen Responsiveness to Preterm Rabbit and Remodeled Human Ductus Arteriosus. Circulation, 110, 1372-1379. https://doi.org/10.1161/01.CIR.0000141292.28616.65

[38] Kajino, H., Goldbarg, S., Roman, C., et al. (2002) Vasavasorum Hypoperfusion Is Responsible for Medial Hypoxia and Anatomic Remodeling in the Newborn Lamb Ductus Arteriosus. Pediatric Research, 51, 228-235. https://doi.org/10.1203/00006450-200202000-00017

[39] Clyman, R.I. (1990) Developmental Physiology of the Ductus Arteriosus. In: Long, W., Ed., Fetal and Neonatal Cardiology, WB (Walter Burns) Saunders, Philadelphia, 64-75.

[40] Kajino, H., Chen, Y., Chemtob, S., et al. (2000) Tissue Hypoxia Inhibits Prostaglan- 
din and Nitric Oxide Production and Prevents Ductus Arteriosus Reopening. American Journal of Physiology-Regulatory, Integrative and Comparative Physiology, 279, R278-R286. https://doi.org/10.1152/ajpregu.2000.279.1.R278

[41] Kitterman, J.A., Edmunds, L.H., Gregory, G.A., Heyman, M.A., Tooley, W.H. and Rudolph, A.M. (1972) Patent Ductus Arteriosus in Premature Infants: Incidence, Relation to Pulmonary Disease and Management. New England Journal of Medicine, 287, 473-477. https://doi.org/10.1056/NEJM197209072871001

[42] Satodo, M., Zhao, F., Diaz, G.A., Burn, J., Goodship, J., Davidson, H.R., Pierpont, M.E. and Gelb, B.D. (2000) Mutations in TFAP2B Cause Char Syndrome, a Familial Form of Patent Ductus Arteriosus. Nature Genetics, 25, 42-46. https://doi.org/10.1038/75578

[43] Satodo, M., Pierpont, M.E., Diaz, G.A., Bornemeier, R.A. and Gelb, B.D. (1999) Char Syndrome. An Inherited Disorder with Patent Ductus Arteriosus, Maps to Chromosome 6p12-p21. Circulation, 99, 3036-3042.

https://doi.org/10.1161/01.CIR.99.23.3036

[44] Mani, A., Meraji, S., Houshayar, R., Radhakrishnan, J., Ahanger, M., Rezaie, T.M., Tagahabinejad, M.A., Broumand, B., Zhao, H., Nelson-Williams, C. and Lifton, R.P. (2002) Finding Genetic Contributions to Sporadic Disease: A Recessive Locus at 12q24 Commonly Contributes to Patent Ductus Arteriosus. Proceedings of the National Academy of Sciences, 99, 15054-15059.

https://doi.org/10.1073/pnas.192582999

[45] Gibson, S. and Lewis, K. (1952) Congenital Heart Disease Following Maternal Rubella During Pregnancy. American Journal of Diseases of Children, 83, 117-119. https://doi.org/10.1001/archpedi.1952.02040070063007

[46] Swan, C., Tostevin, A.L. and Black, G.H.B. (1946) Final Observations on Congenital Defects in Infants Following Infectious Disease during Pregnancy with Special Reference to Rubella. The Medical Journal of Australia, 2, 889-908.

[47] Rutstein, D.B., Nickerson, R.J. and Heald, F.P. (1952) Seasonal Incidence of Patent Ductus Arteriosus and Maternal Rubella. American Journal of Diseases of Children, 84, 199-213.

[48] Alzamora-Castro, V., Battilana, G., Abugattas, R. and Sialer, S. (1960) Patent Ductus Arteriosus and High Altitude. American Journal of Cardiology, 5, 761-763. https://doi.org/10.1016/0002-9149(60)90052-7

[49] Nora, J.J. (1968) Multifactorial Inheritance Hypothesis for the Etiology of Congenital Heart Disaeses: The Genetic-Environmental Interaction. Circulation, 38, 604-617. https://doi.org/10.1161/01.CIR.38.3.604

[50] Anoop, P. and Sasidharan, C.K. (2003) Patent Ductus Arteriosus in Fetal Valproate Syndrome. Indian Journal of Pediatrics, 70, 681-682. https://doi.org/10.1007/BF02724264

[51] Tomita, H., Fuse, S., Hatakeyama, K. and Chiba, S. (1998) Epinephrine-Induced Constriction of the Persistent Ductus Arteriosus and Its Relation to Distensibility. Japanese Circulation Journal, 62, 913-914. https://doi.org/10.1253/jcj.62.913

[52] Eppinger, E., Burwell, S. and Gross, R.E. (1941) The Effects of the Patent Ductus Arteriosus on the Circulation. Journal of Clinical Investigation, 20, 127-143. https://doi.org/10.1172/JCI101205

[53] Fishman, L. and Silverthorne, C. (1951) Persistent Patent Ductus Arteriosus in the Aged. American Heart Journal, 41, 762-769.

https://doi.org/10.1016/0002-8703(51)90266-9 
[54] Bessinger, F.B., Blieden, L.C. and Edwards, J.E. (1975) Hypertensive Pulmonary Vascular Disease Associated with Patent Ductus Arteriosus: Primary or Secondary? Circulation, 52, 157-161. https://doi.org/10.1161/01.CIR.52.1.157

[55] Cross, K. and Kohayashi, C. (1947) Primary Pulmonary Vasular Sclerosis. American Journal of Clinical Pathology, 17, 155. https://doi.org/10.1093/ajcp/17.2.155

[56] Symmers, W. (1952) Necrotizing Pulmonary Arteriopathy Associated with Pulmonary Hypertension. Journal of Clinical Pathology, 5, 36-41. https://doi.org/10.1136/jcp.5.1.36

[57] Rudolph, A.M. (1974) Congenital Diseases of the Heart: Clinical-Physiologic Considerations in Diagnosis and Management. Year Book Medical, Chicago.

[58] Perkett, E.A., Lyons, R.M., Moses, H.L., Brigham, K.L. and Meyrick, B. (1990) Transforming Growth Factor Beta-Activity in Sheep Lung Lymph during the Development of Pulmonary Hypertension. Journal of Clinical Investigation, 86, 1459-1464. https://doi.org/10.1172/JCI114862

[59] Celermajer, D.S., Cullen, S. and Deanfield, J.E. (1993) Impairment of Endothelium-Dependent Pulmonary Artery Relaxation in Children with Congenital Heart Disease and Abnormal Pulmonary Hemodynamics. Circulation, 87, 440-446. https://doi.org/10.1161/01.CIR.87.2.440

[60] Roberts, K.E., McElroy, J.J., Wong, W.P., Yen, E., Widlitz, A., Barst, R.J., Knowles, J.A. and Morse, J.H. (2004) BMPR $_{2}$ (Bone Morphogenetic Protein Receptor ${ }_{2}$ ) Mutations in Pulmonary Arterial Hypertension with Congenital Heart Disease. The European Respiratory Journal, 24, 371-374. https://doi.org/10.1183/09031936.04.00018604

[61] Calne, D.B. and Raftery, E.B. (1966) Patent Ductus Arteriosus in an Elderly Man. British Heart Journal, 28, 716-717. https://doi.org/10.1136/hrt.28.5.716

[62] Cosh, J.A. (1957) Patent Ductus Arteriosus. A Follow-Up Study of 73 Cases. British Heart Journal, 19, 13-22. https://doi.org/10.1136/hrt.19.1.13

[63] Currarino, G. and Jackson, J.H. (1970) Calcification of Ductus Arteriosus and Ligamentum Bottali. Radiology, 94, 139. https://doi.org/10.1148/10.1148/94.1.139

[64] Kelly, D.T. (1979) Patent Ductus Arteriosus in Adults. Cardiovascular Clinics, 10, 321-326.

[65] Huhta, J.C., Cohen, M. and Gurgesell, H.P. (1984) Patency of the Ductus Arteriosus in Normal Neonates: Two Dimensional Echocardiography versus Doppler Assessment. Journal of American College of Cardiology, 4, 561-564.

https://doi.org/10.1016/S0735-1097(84)80102-3

[66] Hiraishi, S., Horiguchi, Y., Misawa, H., Oguchi, K., Kadoi, N., Fujino, N. and Yashiro, K. (1987) Noninvasive Doppler Echocardiographic Evaluation of Shunt Flow Dynamics of the Ductus Arteriosus. Circulation, 75, 1146-1153. https://doi.org/10.1161/01.CIR.75.6.1146

[67] Houston, A.B., Lim, M.K., Doig, W.B., Gnanapragasam, J., Coleman, E.N., Jamieson, M.P.G. and Pollock, J.C.S. (1989) Doppler Flow Characteristics in the Assessment of Pulmonary Artery Pressure in Ductus Arteriosus. British Heart Journal, 62, 284-290. https://doi.org/10.1136/hrt.62.4.284

[68] Feigenbaum, H., Armstrong, W.F. and Ryan, T. (2005) Tricuspid and Pulmonary Valves. In: Feigenbaum, H., Armstrong, W.F. and Ryan, T., Eds., Feigenbaum's Echocardiography, 6th Edition, Chapter 12, Lippincott Williams \& Wilkins, Philadelphia, 355.

[69] Green, T.P., Thompson, T.R., Johnson, D.E., et al. (1983) Furosemide Promotes Pa- 
tent Ductus Arteriosus in Premature Infants with Respiratory Distress Syndrome. New England Journal of Medicine, 308, 743-748. https://doi.org/10.1056/NEJM198303313081303

[70] Koch, J., Hensley, G., Roy, L., et al. (2006) Prevalence of Spontaneous Closure of the Ductus Arteriosus in Neonates at a Birth Weight of 1000 Grams or Less. Pediatrics, 117, 1113-1121. https://doi.org/10.1542/peds.2005-1528

[71] Freed, M.D., Heymann, M.A., Lewis, A.B., et al. (1981) Prostaglandin $E_{1}$ in Infants with Ductus Arteriosus-Dependent Congenital Heart Disease. Circulation, 64, 899-905. https://doi.org/10.1161/01.CIR.64.5.899

[72] Gersony, W.M., Peckham, G.J., Ellison, R.C., et al. (1983) Effects of Indomethacin in Premature Infants with Patent Ductus Arteriosus: Results of a National Collaborative Study. Journal of Pediatrics, 102, 895-906. https://doi.org/10.1016/S0022-3476(83)80022-5

[73] Way, G.L., Pierce, J.R., Wolf, R.R., et al. (1979) ST Depression Suggesting Subendocardial Ischemia in Neonates with Respiratory Distress Syndrome and Patent Ductus Arteriosus. Journal of Pediatrics, 95, 609-611. https://doi.org/10.1016/S0022-3476(79)80780-5

[74] Herrera, C.M., Holberton, J.R. and Davis, P.G. (2007) Prolonged versus Short Course of Indomethacin for the Treatment of Patent Ductus Arteriosus in Preterm Infants. Cochrane Library. https://doi.org/10.1002/14651858.CD003480.pub3

[75] Olgun, H., Ceviz, N., Kartal, I., et al. (2016) Repeated Courses of Oral Ibuprofen in Premature Infants with Patent Ductus Arteriosus: Efficacy and Safety. Pediatrics and Neonatology, 58, 29-35. https://doi.org/10.1016/j.pedneo.2015.04.017

[76] Demir, N., Peker, E, Ece, I., et al. (2017) Efficacy and Safety of Rectal Ibuprofen for Patent Ductus Arteriosus Closure in Very Low Birth Weight Preterm Infants. The Journal of Maternal-Fetal \& Neonatal Medicine, 25, 1-10. https://doi.org/10.1080/14767058.2017.1408064

[77] Bagheri, M.M., Niknafs, P., Sabsevari, F., et al. (2016) Comparison of Oral Acetaminophen versus Ibuprofen in Premature Infants with Patent Ductus Arteriosus. Iran Journal of Pediatrics, 26, e3975. https://doi.org/10.5812/ijp.3975

[78] Khuffash, A.E.L., James, A.T., Cleary, A., Semberova, J., Franklin, O. and Miletin, J. (2018) RCPCH (Royal College of Paediatrics and Child Health) Conference, 13-15 March, Glasgow.

[79] Blok, I.M., Van Riel, A.C., Van Dijk, A.P., Mulder, B.J. and Bouma, B.J. (2017) From Bosentan to Macitentan for Pulmonary Arterial Hypertension and Adult Congenital Heart Disease: Further Improvement? International Journal of Cardiology, 227, 51-52. https://doi.org/10.1016/j.ijcard.2016.11.211

[80] Galie, N., Ghofrani, H.A., Torbicki, A., Barst, R.J., Rubin, L.J., Badesch, D., Fleming, T., Parpia, T., Burgess, G., Branzi, A., et al. (2005) Sildenafil Citrate Therapy for Pulmonary Arterial Hypertension. New England Journal of Medicine, 353, 2148-2157. https://doi.org/10.1056/NEJMoa050010

[81] Ghofrani, H.A., Galie, N., Grimminger, F., Grunig, E., Humbert, M., Jing, Z.C., Keogh, A.M., Langleben, D., Kilama, M.O., Fritsch, A., et al. (2013) Riociguat for the Treatment of Pulmonary Arterial Hypertension. New England Journal of Medicine, 369, 330-340. https://doi.org/10.1056/NEJMoa1209655

[82] Sitbon, O., Channick, R., Chin, K.M., Frey, A., Gaine, S., Galie, N., Ghofrani, H.A., Hoeper, M.M., Lang, I.M., Preiss, R., et al. (2015) Selexipag for the Treatment of Pulmonary Arterial Hypertension. New England Journal of Medicine, 373, 2522-2533. https://doi.org/10.1056/NEJMoa1503184 
[83] Elliot, C.A., Stewart, P., Webster, V.J., Mills, G.H., Hutchinson, S.P., Howarth, E.S., Bu'lock, F.A., Lawson, R.A., Armstrong, U. and Kiely, D.G. (2005) The Use of Ilioprost in Early Pregnancy in Patients with Pulmonary Arterial Hypertension. European Respiratory Journal, 26, 168-173. https://doi.org/10.1183/09031936.05.00128504

[84] Marquis, R.M., Miller, H.D.C., McCormack, R.J.M., et al. (1982) Persistence of Ductus Arteriosus with Left-to-Right Shunt in the Older Patient. British Heart Journal, 48, 469-484. https://doi.org/10.1136/hrt.48.5.469

[85] Porstmann, W., Wierny, L., Warnke, H., et al. (1971) Catheter Closure of Patent Ductus Arteriosus. 62 Cases Treated without Thoracotomy. Radiology Clinics of North America, 9, 203-218.

[86] Rashkind, W.J. (1983) Transcatheter Treatment of Congenital Heart Disease. Circulation, 67, 711-716. https://doi.org/10.1161/01.CIR.67.4.711

[87] Cambier, P.A., Kirby, W.C., Worthan, D.C. and Moore, J.W. (1992) Percutaneous Closure of the Small $(\leq 2.5 \mathrm{~mm})$ Patent Ductus Arteriosus Using Coil Embolization. American Journal of Cardiology, 69, 1412-1420. https://doi.org/10.1016/0002-9149(92)90514-Y

[88] Moore, J.W., Schneider, D.J. and DiMeglio, D. (2001) The Duct-Occlud Device: Design, Clinical Results and Future Directions. Journal of Interventional Cardiology, 14, 231-238. https://doi.org/10.1111/j.1540-8183.2001.tb00741.x

[89] Pass, R.H., Hijazi, Z., Hsu, D.T., Lewis, V. and Hellenbrand, W.E. (2004) Multicenter USA Amplatzer Patent Ductus Arteriosus Occlusion Device Trial: Initial and One Year Results. Journal of American College of Cardiology, 44, 513-519. https://doi.org/10.1016/j.jacc.2004.03.074

[90] Orishi, Y., Okamoto, M., Sueda, T., Hashimoto, M., Karakawa, S. and Akita, T. (1999) Transcatheter Coil Embolization of Large-Size Patent Ductus Arteriosus in Adult Patients. Japanese Circulation Journal, 63, 994-998. https://doi.org/10.1253/jcj.63.994

[91] Zhang, D.Z., Zhu, X.Y., Lv, B., Cui, C.S., Han, X.M., Sheng, X.T., et al. (2014) Trial Occlusion to Assess the Risk of Persistent Pulmonary Arterial Hypertension after Closure of a Large Patent Ductus Arteriosus in Adolescents and Adults with Elevated Pulmonary Artery Pressure. Circulation: Cardiovascular Interventions, 7, 473-481. https://doi.org/10.1161/CIRCINTERVENTIONS.113.001135

[92] Munro, J.C. (1907) Ligation of the Ductus Arteriosus. Annals of Surgery, 46, 335-338. https://doi.org/10.1097/00000658-190709000-00003

[93] Gross, R.E. and Hubbard, J.P. (1939) Ductus Arteriosus: Surgical Ligation of a Patent Ductus Arteriosus. Journal of American Medical Association, 8, 729-731. https://doi.org/10.1001/jama.1939.02800080049011

[94] Wright, J.S. and Newman, D.C. (1978) Ligation of the Patent Ductus. Journal of Thoracic and Cardiovascular Surgery, 75, 695-698.

[95] Yangni-Angate, H., Ayegnon, G., Meneas, C., Diby, F.L. and Yapobi, Y. (2007) Patent Ductus Arteriosus in Adults: Surgical Experience in Ivory Coast. Annals of African Medicine, 6, 34-35. https://doi.org/10.4103/1596-3519.55732

[96] Diller, G.P., Dimopoulos, K., Kafka, H. and Ho, S.Y. (2007) Model of Chronic Adaptation. Right Ventricular Function in Eisenmenger Syndrome. European Heart Journal, 9, H54-H60. https://doi.org/10.1093/eurheartj/sum019

[97] Raymond, T.E., Khabbaza, J.E., Yadav, R. and Tonelli, A.R. (2014) Significance of Main Pulmonary Artery Dilation on Imaging Studies. Annals of the American 
Thoracic Society, 11, 1623-1632. https://doi.org/10.1513/AnnalsATS.201406-253PP

[98] Shazly Mahamoud, S.E., Ali, S.H., Reda, A. and El Sisi, A. (2018) Challenges of Percutaneous Closure of Patent Ductus Arteriosus in Adolescents and Adults: Single Center Experience. Cardiology \& Angiology: An International Journal, 7, 1-8. https://doi.org/10.9734/CA/2018/37922 